\title{
OPTIMASI PEMILIHAN LAYANAN STREAMING MULTIMEDIA BERBASIS UPnP UNTUK KONDISI DINAMIS
}

\author{
Fariz Andri Bakhtiar1, Waskitho Wibisono², Baskoro Adi Pratomo ${ }^{3}$ \\ ${ }^{1}$ Mahasiswa Program Pascasarjana Teknik Informatika Institut Teknologi Sepuluh November, Surabaya, \\ Indonesia \\ ${ }^{2}$ Dosen Program Pascasarjana Teknik Informatika Institut Teknologi Sepuluh November, Surabaya, Indonesia \\ ${ }^{3}$ Dosen Program Pascasarjana Teknik Informatika Institut Teknologi Sepuluh November, Surabaya, Indonesia \\ Email: ${ }^{1}$ fariz10@mhs.if.its.ac.id, ${ }^{2}$ waswib@if.its.ac.id, ${ }^{3}$ baskoro@if.its.ac.id
}

(Naskah masuk: 18 Februari 2016, diterima untuk diterbitkan: 17 Maret 2016)

\begin{abstract}
Abstrak
Universal Plug and Play (UPnP) memungkinkan adanya jaringan tanpa konfigurasi dan administrasi manual. UPnP bekerja pada jaringan yang mendukung pesan multicast. Ia mengatur pengalamatan, penemuan, deskripsi, serta pemilihan perangkat dan layanan. Proses penemuan layanan dalam lingkungan dinamis harus mengurangi konfigurasi manual, memungkinkan penemuan otomatis dan pemilihan layanan yang optimal, serta menawarkan secara terkini layanan-layanan yang tersedia. Pada kondisi di mana beberapa host menyediakan layanan yang sama, bagaimana klien memilih layanan menjadi permasalahan tersendiri. Pemilihan layanan yang paling sesuai dapat dilakukan secara otomatis oleh klien UPnP. Pemilihan layanan dilaksanakan berdasarkan parameter yang mencerminkan kondisi jaringan saat itu, seperti delay dan packet loss. Pada aplikasi-aplikasi streaming multimedia berbasis UPnP yang ada, pemilihan layanan dilakukan tanpa penentuan prioritas sama sekali. Aplikasi klien mengambil begitu saja salah satu layanan streaming multimedia dari sejumlah perangkat penyedia layanan di jaringan, bahkan secara acak. Implementasi aplikasi streaming multimedia di lingkungan dinamis menyebabkan perlunya optimasi terhadap mekanisme pemilihan layanan yang sudah ada. Pada penelitian ini diusulkan metode dalam melakukan optimasi pada pemilihan layanan streaming multimedia berbasis UPnP untuk kondisi dinamis, yaitu kondisi di mana dapat terjadi perubahan pada delay, packet loss, dan ketersediaan layanan. Dari hasil percobaan, terbukti bahwa optimasi tersebut menurunkan end-to-end delay ratarata antara klien dengan penyedia layanan streaming multimedia sebesar 35,343\%, meski terdapat anomali pada beberapa skenario, yaitu naiknya end-to-end delay rata-rata, yang bisa jadi dipengaruhi oleh peningkatan beban kerja penyedia layanan.
\end{abstract}

Kata kunci: pemilihan layanan, streaming, UPnP

\begin{abstract}
Universal Plug and Play (UPnP) enables networking without manual configuration and administration. UPnP works at a network supporting multicast messages. It arranges addressing, discovery, description, and also device and service selection. The process of service discovery in dynamic environment should reduce manual configuration, enable automatic discovery and optimal service selection, and also offer up-to-date services available. In a condition where some hosts run same services, how clients select them becomes one interesting issue. The selection of the most appropriate service is to be done automatically by UPnP clients. Service selection will be held based on current condition of the network, such as delay and packet loss. On existing multimedia streaming applications, service selection is done without any prioritizing. Client applications just fetch a service from a number of service providers in the network, even randomly. Implementations of multimedia streaming applications in dynamic environment, where there might be changes on delay, packet loss, and the availability of services at service providers, causes the urgency of optimization in existing service selection mechanism. In this study, a method of optimizing the UPnP-based service selection of multimedia streaming for dynamic condition is proposed. Experiments prove that the optimization reduces average end-to-end delay between clients and multimedia streaming service providers at the rate of $35.343 \%$. There were anomalies at some scenarios though. Some delay grew higher, which could be affected by the increase of service providers' load.
\end{abstract}

Keywords: service selection, streaming, $U P n P$

\section{PENDAHULUAN}

Teknologi UPnP mendefinisikan arsitektur untuk konektivitas jaringan pervasive secara peer-to- peer antara perangkat-perangkat yang terhubung melalui kabel/nirkabel. UPnP menyediakan konektivitas kepada jaringan ad-hoc atau nolkonfigurasi, dan penemuan beragam jenis perangkat dari berbagai vendor secara otomatis. Perangkat 
UPnP dapat secara dinamis bergabung di sebuah jaringan, memperoleh alamat IP, mengumumkan layanannya, serta mendapat informasi tentang adanya perangkat lain dan layanan yang ditawarkan (UPnP FORUM, 2015).

UPnP bekerja pada jaringan yang mendukung pesan multicast. Ia memungkinkan pengalamatan, penemuan, deskripsi, dan pemilihan perangkat dan layanan. UPnP dibangun di atas beberapa teknologi open source seperti Simple Object Access Protocol (SOAP), HyperText Transfer Protocol (HTTP), dan eXtensible Markup Languange (XML), berdasarkan konsep perangkat sebagai wadah layanan. Setiap layanan memiliki deskripsi yang mencakup keadaan default, sejumlah event yang dapat dilanggan, dan deskripsi fungsi layanan dengan tindakan yang dapat dipanggil (GRIMMETT \& O’NEILL, 2012).

Tahap pemilihan layanan dilakukan klien peminta layanan setelah terkumpulnya informasi tentang layanan yang diminta. Pemilihan layanan dapat dilakukan secara otomatis (VERVERIDIS \& POLYZOS, 2008). Contoh pendekatan sederhananya ialah memilih layanan berdasarkan kondisi jaringan saat itu, seperti delay dan packet loss.

Kondisi dinamis yang berkaitan dengan streaming multimedia meliputi keadaan di mana parameter-parameter yang terlibat di dalamnya rentan mengalami perubahan. Termasuk di antara contoh-contohnya antara lain berubahnya nilai endto-end delay antara klien dengan penyedia layanan streaming, persentase packet loss yang dapat terjadi di antara keduanya, serta ketersediaan layanan pada penyedia layanan.

Pada aplikasi-aplikasi streaming multimedia berbasis UPnP yang ada, pemilihan layanan dilakukan tanpa penentuan prioritas sama sekali. Aplikasi klien mengambil begitu saja salah satu layanan streaming multimedia dari sejumlah perangkat penyedia layanan di jaringan, bahkan secara acak (GUAN dkk., 2007). Implementasi aplikasi streaming multimedia di lingkungan dinamis menyebabkan perlunya optimasi terhadap mekanisme pemilihan layanan yang sudah ada. Dalam penelitian ini diusulkan metode dalam melakukan optimasi pemilihan layanan streaming multimedia berbasis UPnP untuk kondisi dinamis. Metode yang digunakan menerapkan penskoran berdasarkan parameter end-to-end delay antara klien dengan penyedia layanan streaming dan packet loss yang dapat terjadi di penyedia layanan streaming. Berbeda dengan mekanisme pemilihan layanan streaming multimedia berbasis UPnP secara bawaan, yang tidak mempertimbangkan parameter-parameter tersebut.

End-to-end delay merupakan waktu total yang dibutuhkan untuk mentransmisikan paket sepanjang jalur yang dilaluinya, sejak dari aplikasi tempat paket tersebut berasal, hingga sampai di tempat tujuannya. Jenis delay ini didapatkan dengan mengakumulasikan setiap nodal delay pada setiap titik (node) router di jaringan. Nodal delay sendiri merupakan penjumlahan dari processing delay, queueing delay, transmission delay, dan propagation delay (KUROSE \& ROSS, 2013). Pengukuran terhadap delay dapat dilakukan menggunakan utilitas ping, untuk mengetahui round-trip time (RTT) total. RTT merupakan waktu yang dibutuhkan untuk mentransmisikan paket ke tujuan hingga ia kembali lagi ke pengirim semula (NSRC, 2016).

Antrian di tiap node mempunyai batasan maksimum sesuai kapasitas memorinya. Paket yang datang di sebuah router bisa jadi menjumpai kondisi antrian yang penuh. Karena tidak ada tempat penyimpanan tersedia, router akan membuang (drop) paket tersebut. Kejadian ini disebut buffer overflow, yaitu meluapnya buffer (bagian dari memori kom-puter untuk penyimpanan data yang dikirimkan/ diterima ke/dari perangkat eksternal) di router. Dibuangnya paket oleh router menyebabkan hilang-nya paket (packet loss). Seiring dengan meningkat-nya intensitas trafik di jaringan, potensi packet loss juga turut bertambah. Maka, selain menggunakan parameter delay, performa pada sebuah node sering diukur dengan probabilitas packet loss (KUROSE \& ROSS, 2013).

Tujuan dari metode ini adalah untuk memperkecil end-to-end delay antara klien peminta layanan dengan penyedia layanan. Semakin rendah besaran delay, semain baik performa layanan streaming multimedia.

\section{UPnP}

Cara kerja UPnP seperti dikemukakan oleh (HKCERT, 2013) meliputi beberapa proses, yaitu Pengalamatan (Addressing), Penemuan (Discovery), Deskripsi (Description), Kendali (Control), Notifikasi event (Event notification), dan Presentasi (Presentation).

\subsection{Pengalamatan (Addressing)}

Ketika perangkat berkemampuan UPnP dihubungkan dengan jaringan, perangkat tersebut akan berupaya mendapatkan alamat Internet Protocol (IP) melalui protokol Dynamic Host Configuration Protocol (DHCP).

\subsection{Penemuan (Discovery)}

Penemuan layanan UPnP di jaringan dikendalikan oleh protokol Simple Service Discovery Protocol (SSDP). Ketika ada perangkat terpasang di sebuah jaringan dan telah mendapatkan alamat dengan baik, ia akan mengumumkan layananlayanan yang dimilikinya kepada UPnP Control Point yang ada di jaringan tersebut. Perangkat tersebut mengirimkan pesan penemuan (discovery message) kepada alamat multicast di nomor port 1900, melalui protokol User Datagram Protocol 
(UDP). Kemudian, UPnP Control Point dapat melakukan penemuan terhadap layanan-layanan yang disediakan oleh perangkat-perangkat yang ada di dalam jaringan tersebut.

\subsection{Deskripsi (Description)}

Begitu perangkat-perangkat yang menyediakan layanan telah ditemukan, UPnP Control Point akan mendapatkan deskripsi tentang perangkat-perangkat tersebut dan informasi detail tentang layananlayanan dari alamat yang disediakan oleh perangkatperangkat dalam pesan penemuan. Tahap deskripsi bisa jadi mengandung beberapa informasi antara lain nama produk perangkat, nama model perangkat, nomor seri perangkat, identitas (ID) vendor, dan layanan-layanan yang tertanam.

\subsection{Kendali (Control)}

Setelah sebuah UPnP Control Point mendapatkan deskripsi dan informasi detail tentang layanan dari sebuah perangkat, maka perangkat tersebut akan dapat dikendalikan oleh UPnP Control Point melalui pesan-pesan kontrol yang dituliskan dalam eXtensible Markup Language (XML) menggunakan Simple Object Access Protocol (SOAP). Permintaan terhadap layanan tertentu dapat dilakukan dengan mengirimkan pesan SOAP kepada UPnP Control Point menggunakan parameterparameter yang benar, sehingga permintaan tersebut akan diproses dan menghasilkan keluaran dalam bentuk pesan SOAP juga.

\subsection{Notifikasi event (Event notification)}

"Variabel-variabel keadaan (state)" digunakan untuk menyimpan beberapa bentuk keadaan dalam perangkat-perangkat dan program-program UPnP. Sebuah program dapat berlangganan kepada perubahan keadaan. Jika ada pembaharuan pada layanan yang disediakan saat sebuah variabel keadaan berubah, maka pesan event dengan keadaan yang baru akan dikirimkan kepada semua program/ perangkat yang telah berlangganan pada event tersebut.

\subsection{Presentasi (Presentation)}

Tahap presentasi merujuk pada antarmuka yang dapat dikendalikan oleh manusia. Contohnya antarmuka web pada sebuah router yang memungkinkan pengguna melakukan konfigurasi dan mengendalikan perangkat-perangkat yang ada.

\section{PEMILIHAN LAYANAN}

Proses identifikasi layanan, yang dikenal sebagai penemuan layanan (service discovery), merupakan bagian penting dari Service Oriented Architecture (SOA). Arsitektur penemuan layanan yang dijalankan pada lingkungan dinamis harus dapat mengurangi konfigurasi manual, memungkinkan penemuan yang terjadi secara otomatis dan pemilihan layanan yang relevan, serta menawarkan gambaran lengkap dan terkini dari layanan-layanan yang tersedia pada titik waktu tertentu (JOHNSEN dkk., 2008).

Tahap pemilihan layanan dilakukan klien peminta layanan setelah terkumpulnya informasi tentang layanan yang diminta. Pemilihan layanan dapat dilakukan secara otomatis (VERVERIDIS \& POLYZOS, 2008). Contoh pendekatan sederhananya ialah memilih layanan berdasarkan kondisi jaringan saat itu, seperti delay dan packet loss.

\section{MEKANISME PEMILIHAN LAYANAN}

Mekanisme pemilihan layanan yang dirancang dalam penelitian ini diimpelentasikan dalam Bash scripting, sebagai pendamping Grilo Plugins pada Totem Movie Player versi 3.0.1 yang dijalankan pada sistem operasi Linux Ubuntu 12.04 LTS. Mekanisme tersebut berjalan pada application layer di sisi klien UPnP. Pada tiap perangkat yang berkomunikasi diterapkan protokol UPnP agar dapat saling terhubung satu sama lain. Dalam protokol UPnP terdapat mekanisme pemilihan layanan. Untuk keperluan optimasi, mekanisme pemilihan layanan tersebut perlu disesuaikan dengan kriteria-kriteria pemilihan layanan streaming multimedia.

Setelah mendapatkan informasi berupa layanan yang tersedia beserta lokasi penyedia layanannya, klien melakukan mekanisme pemilihan layanan, didasarkan pada kriteria-kriteria berikut:

- End-to-end delay antara klien dengan penyedia layanan.

- Packet loss pada link antara klien dengan penyedia layanan.

Keputusan pemilihan layanan oleh klien didasarkan pada penskoran dengan metode yang didefinisikan pada Rumus (1) berikut (DATA, 2014):

$$
P_{I P}=\left(b_{1} \times\left(1-D_{I P}\right)\right)+\left(b_{2} \times\left(1-L_{I P}\right)\right)(1)
$$

$P_{I P}$ adalah nilai prioritas pemilihan layanan untuk setiap alamat $I P$ yang menyediakan layanan streaming multimedia. Semakin besar nilai $P_{I P}$, makin tinggi tingkat prioritasnya. $b_{1}$ dan $b_{2}$ masingmasing mewakili nilai bobot delay dan bobot packet loss, dengan $\left(0 \leq b_{1} \leq 1\right)$ dan $\left(0 \leq b_{2} \leq 1\right)$, di mana $\left(b_{1}+b_{2}=1\right)$. Besar nilai bobot ditentukan oleh pengguna. $D_{I P}$-dalam satuan millisecond (ms)adalah nilai end-to-end delay antara klien dengan perangkat penyedia layanan yang beralamatkan IP, sedangkan $L_{I P}$ (dalam satuan persen) adalah packet loss pada link antara klien dan perangkat penyedia layanan yang beralamatkan $I P$.

Implementasi mekanisme optimasi pemilihan layanan streaming multimedia pada penelitian ini dilaksanakan menggunakan Algoritma 1. 


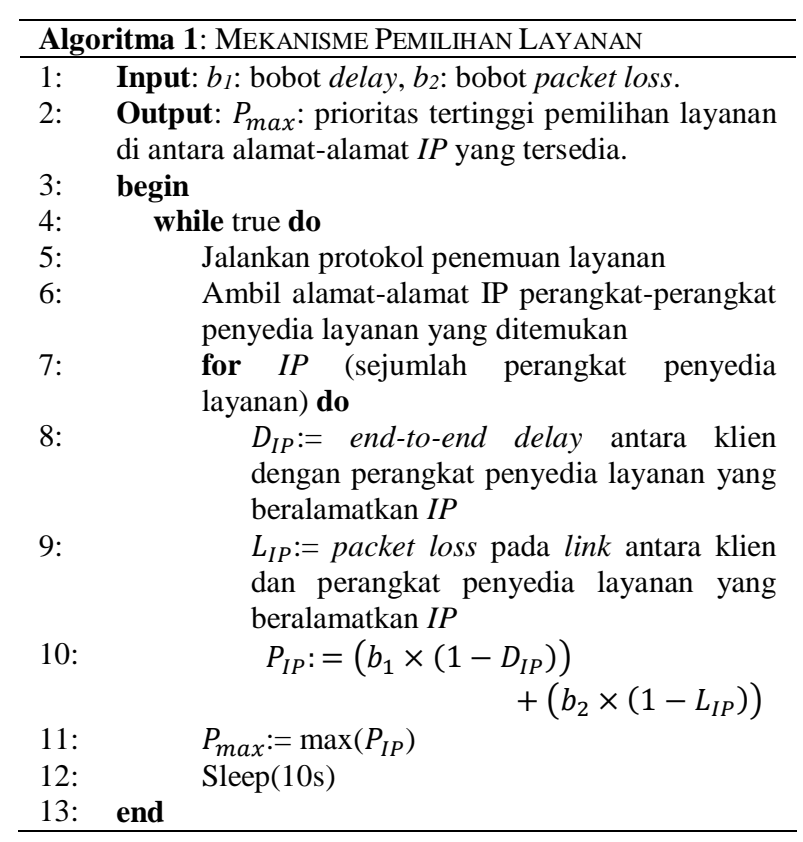

\section{HASIL DAN ANALISIS}

Implementasi dan pengujian dilakukan menggunakan enam host. Tiga host di antaranya berperan sebagai UPnP Root Device (UPnP Media Server), yaitu host RootDevice1 (RD1), RootDevice2 (RD2), dan RootDevice3 (RD3). Sedangkan tiga host lainnya berperan sebagai $U P n P$ Client (UPnP Media Renderer), yaitu host VMUbuntu12045_1 (C1), VMUbuntu12045_2 (C2), dan VMUbuntu12045_3 (C3). Keenam host tersebut berada dalam satu subnet yang sama, dengan topologi jaringan testbed dan konfigurasi alamat Internet Protocol (IP) masing-masing host seperti terlihat pada Gambar 1.

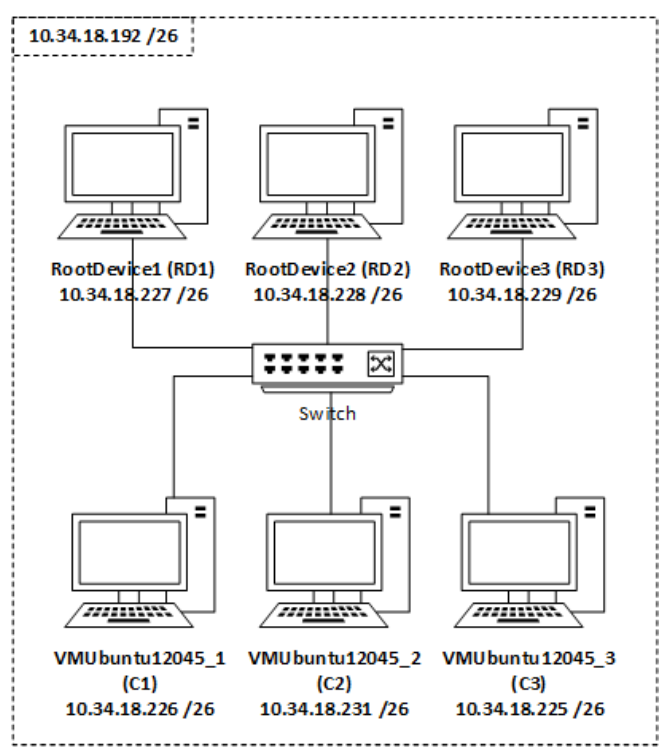

Gambar 1. Topologi jaringan testbed dan konfigurasi alamat IP tiap host dalam implementasi \& pengujian

\subsection{Pengaruh Delay}

Kebutuhan Quality of Service (QoS) untuk streaming audio/video antara lain toleransi delay hingga sebesar $150 \mathrm{~ms}$ (SZIGETI \& HATTINGH, 2004). Pengujian pengaruh delay dilakukan dengan mensimulasikan delay menggunakan Netem pada beberapa host penyedia layanan streaming multimedia, dan membiarkan satu host penyedia layanan tanpa delay. Penambahan delay disimulasikan sebesar $50 \mathrm{~ms}$ dan $150 \mathrm{~ms}$ dengan toleransi $\pm 10 \mathrm{~ms}$.

Tabel 1. Skenario Pengaruh Delay

\begin{tabular}{|c|c|c|c|}
\hline \multirow{2}{*}{$\begin{array}{c}\text { Skenario } \\
\text { No. }\end{array}$} & \multicolumn{3}{|c|}{ Delay Tambahan (ms) } \\
\hline & RD1 & RD2 & RD3 \\
\hline 1 & 0 & 0 & 0 \\
\hline 2 & 0 & 0 & 50 \\
\hline 3 & 0 & 0 & 150 \\
\hline 4 & 0 & 50 & 50 \\
\hline 5 & 0 & 50 & 150 \\
\hline 6 & 0 & 150 & 150 \\
\hline
\end{tabular}

Tabel 1 menunjukkan skenario-skenario pengujian pengaruh delay. Pada tiap skenario diatur penambahan delay secara sengaja pada masingmasing host RD1, RD2, dan RD3 dengan kombinasi nilai delay yang berbeda-beda, untuk melihat pengaruh delay terhadap mekanisme pemilihan layanan. Detail masing-masing skenario pengujian pada Tabel 1 yaitu sebagai berikut:

1. Pada RD1, RD2, dan RD3 tidak diberikan delay tambahan.

2. Pada RD1 dan RD2 tidak diberikan delay tambahan, sedangkan pada RD3 diberikan delay tambahan sebesar $50 \mathrm{~ms}$.

3. Pada RD1 dan RD2 tidak diberikan delay tambahan, sedangkan pada RD3 diberikan delay tambahan sebesar $150 \mathrm{~ms}$.

4. Pada RD1 tidak diberikan delay tambahan, sedangkan pada RD2 dan RD3 diberikan delay tambahan masing-masing sebesar $50 \mathrm{~ms}$.

5. Pada RD1 tidak diberikan delay tambahan, sedangkan pada RD2 dan RD3 diberikan delay tambahan masing-masing sebesar $50 \mathrm{~ms}$ dan $150 \mathrm{~ms}$.

6. Pada RD1 tidak diberikan delay tambahan, sedangkan pada RD2 dan RD3 diberikan delay tambahan masing-masing sebesar $150 \mathrm{~ms}$.

Pada tiap skenario diukur end-to-end delay rata-rata antara masing-masing klien dengan penyedia layanan, baik sebelum maupun sesudah dilakukan optimasi pada mekanisme pemilihan layanan.

Hasilnya, setelah dilakukan optimasi, klien selalu memilih layanan yang disediakan oleh penyedia layanan dengan end-to-end delay terendah. Hal tersebut berbeda dengan keadaan praoptimasi, dalam mana klien tidak selalu memilih layanan yang disediakan oleh penyedia layanan dengan end-to-end delay terendah, bahkan pada beberapa skenario klien 
memilih layanan yang disediakan oleh penyedia layanan dengan end-to-end delay tertinggi.

Perbandingan rata-rata end-to-end delay antara klien $(\mathrm{C} 1, \mathrm{C} 2$, dan $\mathrm{C} 3)$ dengan penyedia layanan untuk pengujian pengaruh delay, pada penerapan mekanisme pemilihan layanan sebelum dioptimasi dan sesudah dioptimasi, dapat dilihat pada Tabel 2, Tabel 3, dan Tabel 4. Dalam bentuk grafik, data perbandingan tersebut ditunjukkan pada Gambar 2, Gambar 3, dan Gambar 4.

Tabel 2. Rerata End-to-End Delay antara C1 dan Penyedia Layanan, pada Pengujian Pengaruh Delay

\begin{tabular}{ccc}
\hline $\begin{array}{c}\text { Skenario } \\
\text { No. }\end{array}$ & \multicolumn{2}{c}{ Rerata End-to-End Delay C1 $(\mathbf{m s})$} \\
\cline { 2 - 3 } & Praoptimasi & Pascaoptimasi \\
\hline 1 & 1,603 & 1,500 \\
2 & 1,487 & 1,448 \\
3 & 1,911 & 1,725 \\
4 & 1,839 & 1,848 \\
5 & 53,053 & 1,919 \\
6 & 1,648 & 1,684 \\
\hline Rata-rata & 10,257 & 1,687 \\
\hline
\end{tabular}

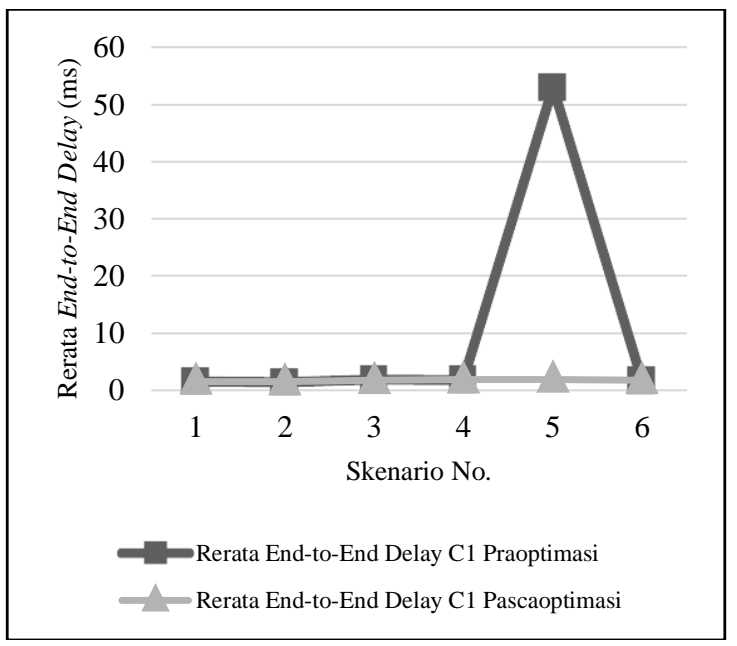

Gambar 2. Grafik Rerata End-to-End Delay antara C1 dan Penyedia Layanan, pada Pengujian Pengaruh Delay

Tabel 3. Rerata End-to-End Delay antara C2 dan Penyedia Layanan, pada Pengujian Pengaruh Delay

\begin{tabular}{ccc}
\hline Skenario & \multicolumn{2}{c}{ Rerata End-to-End Delay C2 (ms) } \\
\cline { 2 - 3 } No. & Praoptimasi & Pascaoptimasi \\
\hline 1 & 1,276 & 1,249 \\
2 & 1,271 & 1,204 \\
3 & 1,207 & 1,229 \\
4 & 1,256 & 1,200 \\
5 & 51,258 & 1,329 \\
6 & 1,277 & 1,254 \\
\hline Rata-rata & 9,591 & 1,244 \\
\hline
\end{tabular}

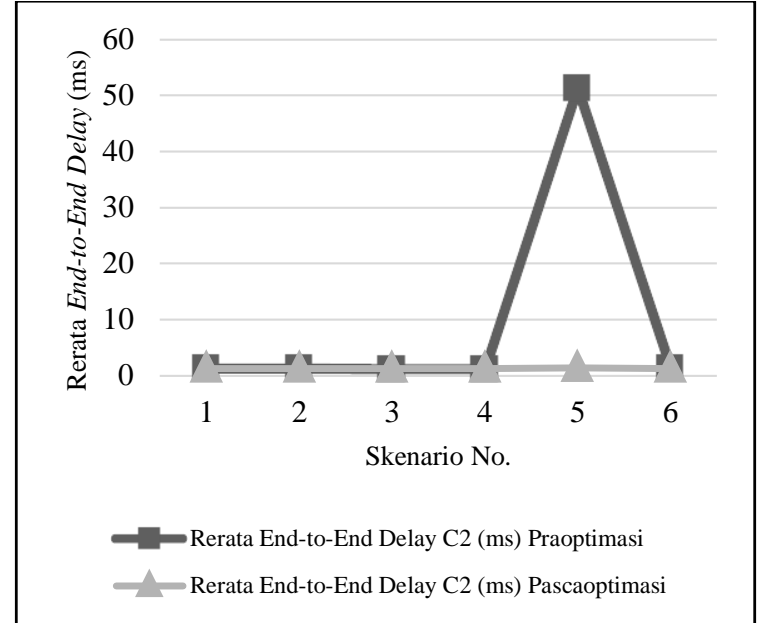

Gambar 3. Grafik Rerata End-to-End Delay antara C2 dan Penyedia Layanan, pada Pengujian Pengaruh Delay

Tabel 4. Rerata End-to-End Delay antara C3 dan Penyedia Layanan, pada Pengujian Pengaruh Delay

\begin{tabular}{ccc}
\hline $\begin{array}{c}\text { Skenario } \\
\text { No. }\end{array}$ & \multicolumn{2}{c}{ Rerata End-to-End Delay C3 $(\mathbf{m s})$} \\
\cline { 2 - 3 } & Praoptimasi & Pascaoptimasi \\
\hline 1 & 1,891 & 1,748 \\
2 & 51,766 & 1,729 \\
3 & 1,724 & 1,710 \\
4 & 1,726 & 1,620 \\
5 & 1,693 & 1,649 \\
6 & 101,623 & 1,754 \\
\hline Rata-rata & 26,737 & 1,702 \\
\hline
\end{tabular}

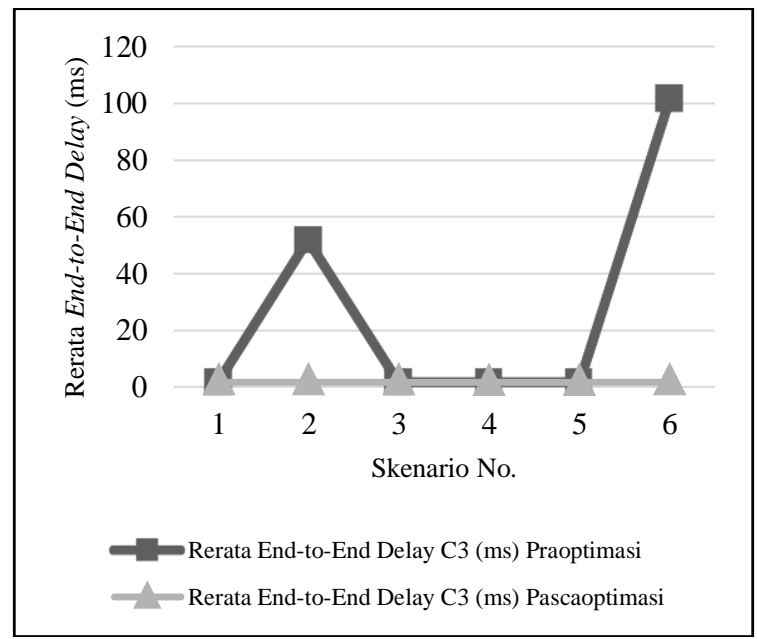

Gambar 4. Grafik Rerata End-to-End Delay antara C3 dan Penyedia Layanan, pada Pengujian Pengaruh Delay

Pada Tabel 2, Tabel 3, dan Tabel 4 ditunjukkan bahwa optimasi pemilihan layanan mampu menekan end-to-end delay rata-rata antara setiap klien dengan penyedia layanan yang terpilih. Pada beberapa skenario (C1 skenario 5, C2 skenario 5, C3 skenario 2, dan C3 skenario 6), selisih end-to-end delay sebelum dan sesudah optimasi cukup signifikan, 
dengan persentase penurunan masing-masing sebesar 96,383\%, 97,407\%, 96,660\%, dan 98,274\%.

Adapun persentase penurunan end-to-end delay rata-rata pada pengujian pengaruh delay untuk $\mathrm{C} 1$, C2, dan C3 antara sebelum dan sesudah optimasi pemilihan layanan masing-masing sebesar $83,549 \%$, $87,028 \%$, dan $93,636 \%$. Dari ketiga nilai persentase tersebut, didapatkan rata-rata penurunan end-to-end delay pada pengujian pengaruh delay sebesar $88,071 \%$.

\subsection{Pengaruh Packet Loss}

Kebutuhan QoS untuk streaming audio/video antara lain persentase packet loss yang tak lebih dari 1\% (SZIGETI \& HATTINGH, 2004). Dalam pengujian pengaruh packet loss, dibangkitkan packet loss menggunakan Netem pada beberapa host penyedia layanan, salah satu host penyedia layanan dibiarkan tanpa packet loss. Penambahan packet loss disimulasikan sebesar $0,5 \%$ dan $1 \%$.

Tabel 5. Skenario Pengaruh Packet Loss

\begin{tabular}{cccc}
\hline Skenario & \multicolumn{3}{c}{ Packet Loss Tambahan (\%) } \\
\cline { 2 - 4 } No. & RD1 & RD2 & RD3 \\
\hline 1 & 0 & 0 & 0 \\
2 & 0 & 0 & 0,5 \\
3 & 0 & 0 & 1 \\
4 & 0 & 0,5 & 0,5 \\
5 & 0 & 0,5 & 1 \\
6 & 0 & 1 & 1 \\
\hline
\end{tabular}

Tabel 5 menunjukkan skenario-skenario pengujian pengaruh packet loss. Pada tiap skenario diatur penambahan packet loss secara sengaja pada masing-masing host RD1, RD2, dan RD3 dengan kombinasi nilai packet loss yang berbeda-beda, untuk melihat pengaruh packet loss terhadap mekanisme pemilihan layanan. Detail masingmasing skenario pengujian pada Tabel 5 yaitu sebagai berikut:

1. Pada RD1, RD2, dan RD3 tidak diberikan packet loss tambahan.

2. Pada RD1 dan RD2 tidak diberikan packet loss tambahan, sedangkan pada RD3 diberikan packet loss tambahan sebesar 0,5\%.

3. Pada RD1 dan RD2 tidak diberikan packet loss tambahan, sedangkan pada RD3 diberikan packet loss tambahan sebesar $1 \%$.

4. Pada RD1 tidak diberikan packet loss tambahan, sedangkan pada RD2 dan RD3 diberikan packet loss tambahan masing-masing sebesar $0,5 \%$.

5. Pada RD1 tidak diberikan packet loss tambahan, sedangkan pada RD2 dan RD3 diberikan packet loss tambahan masing-masing sebesar $0,5 \%$ dan $1 \%$.

6. Pada RD1 tidak diberikan packet loss tambahan, sedangkan pada RD2 dan RD3 diberikan packet loss tambahan masing-masing sebesar $1 \%$.
Pada tiap skenario diukur end-to-end delay rata-rata antara masing-masing klien dengan penyedia layanan, baik sebelum maupun sesudah dilakukan optimasi pada mekanisme pemilihan layanan.

Hasilnya, setelah optimasi, klien selalu memilih layanan yang disediakan oleh penyedia layanan dengan end-to-end delay terendah, seperti pada pengujian pengaruh delay. Hal tersebut berbeda dengan keadaan praoptimasi.

Perbandingan rata-rata end-to-end delay antara klien $(\mathrm{C} 1, \mathrm{C} 2$, dan $\mathrm{C} 3)$ dengan penyedia layanan untuk pengujian pengaruh packet loss, pada penerapan mekanisme pemilihan layanan sebelum dioptimasi dan sesudah dioptimasi, dapat dilihat pada Tabel 6, Tabel 7, dan Tabel 8. Dalam bentuk grafik, data perbandingan tersebut ditunjukkan pada Gambar 5, Gambar 6, dan Gambar 7.

Tabel 6. Rerata End-to-End Delay antara C1 dan Penyedia Layanan, pada Pengujian Pengaruh Packet Loss

\begin{tabular}{ccc}
\hline Skenario & \multicolumn{2}{c}{ Rerata End-to-End Delay C1 $(\mathbf{m s})$} \\
\cline { 2 - 3 } No. & Praoptimasi & Pascaoptimasi \\
\hline 1 & 1,543 & 1,502 \\
2 & 1,537 & 1,503 \\
3 & 2,152 & 2,192 \\
4 & 1,933 & 1,939 \\
5 & 2,226 & 2,149 \\
6 & 2,406 & 2,147 \\
\hline Rata-rata & 1,966 & 1,905 \\
\hline
\end{tabular}

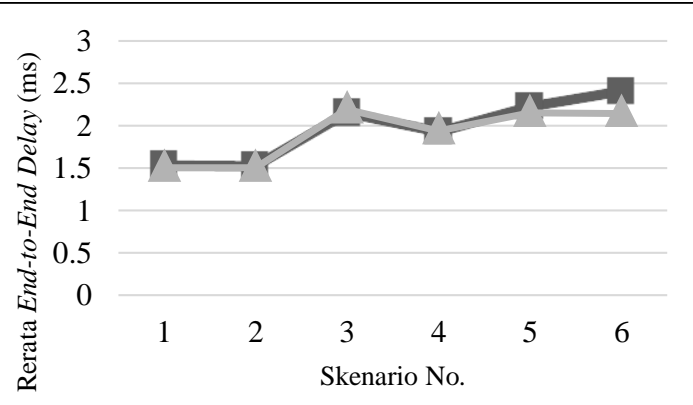

Rerata End-to-End Delay C1 (ms) Praoptimasi __ Rerata End-to-End Delay C1 (ms) Pascaoptimasi

Gambar 5. Grafik Rerata End-to-End Delay antara $\mathrm{C} 1$ dan Penyedia Layanan, pada Pengujian Pengaruh Packet Loss

Tabel 7. Rerata End-to-End Delay antara C2 dan Penyedia Layanan, pada Pengujian Pengaruh Packet Loss

\begin{tabular}{ccc}
\hline Skenario & \multicolumn{2}{c}{ Rerata End-to-End Delay C2 $(\mathbf{m s})$} \\
\cline { 2 - 3 } No. & Praoptimasi & Pascaoptimasi \\
\hline 1 & 1,272 & 1,205 \\
2 & 1,252 & 1,23 \\
3 & 1,315 & 1,229 \\
4 & 1,275 & 1,259 \\
5 & 1,334 & 1,201 \\
6 & 1,247 & 1,229 \\
\hline Rata-rata & 1,283 & 1,226 \\
\hline
\end{tabular}




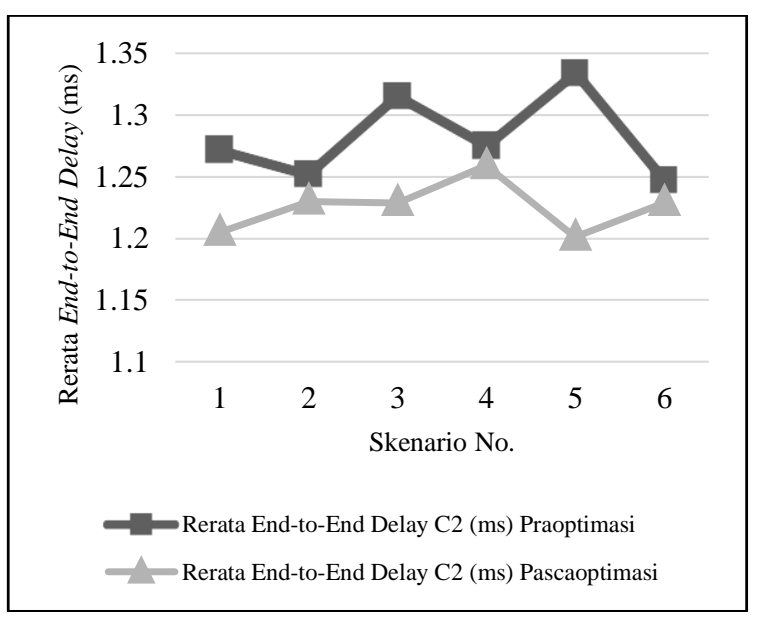

Gambar 6. Grafik Rerata End-to-End Delay antara C2 dan Penyedia Layanan, pada Pengujian Pengaruh Packet Loss

Tabel 8. Rerata End-to-End Delay antara C3 dan Penyedia Layanan, pada Pengujian Pengaruh Packet Loss

\begin{tabular}{ccc}
\hline $\begin{array}{c}\text { Skenario } \\
\text { No. }\end{array}$ & \multicolumn{2}{c}{ Rerata End-to-End Delay C3 $(\mathbf{m s})$} \\
\cline { 2 - 3 } & Praoptimasi & Pascaoptimasi \\
\hline 1 & 1,743 & 1,794 \\
2 & 1,745 & 1,739 \\
3 & 1,942 & 1,739 \\
4 & 1,699 & 1,692 \\
5 & 1,937 & 1,694 \\
6 & 2,032 & 1,729 \\
\hline Rata-rata & 1,850 & 1,731 \\
\hline
\end{tabular}

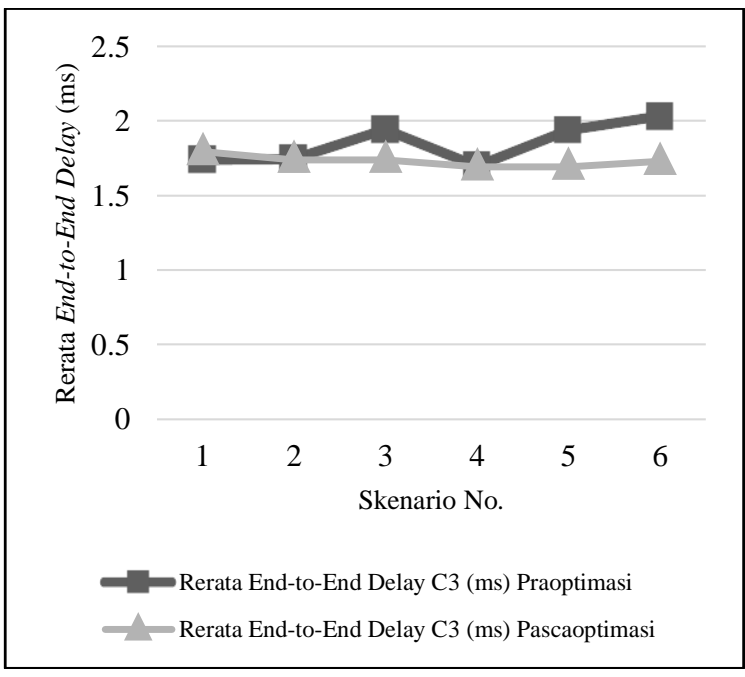

Gambar 7. Grafik Rerata End-to-End Delay antara C3 dan Penyedia Layanan, pada Pengujian Pengaruh Packet Loss

Pada Tabel 6, Tabel 7, dan Tabel 8 ditunjukkan bahwa optimasi pemilihan layanan mampu menekan end-to-end delay rata-rata antara setiap klien dengan penyedia layanan yang terpilih, meskipun dengan selisih yang kurang signifikan dibanding perbandingan end-to-end delay rata-rata pada pengujian pengaruh delay.

Persentase penurunan end-to-end delay ratarata pada pengujian pengaruh packet loss untuk $\mathrm{C} 1$, C2, dan C3 antara sebelum dan sesudah optimasi pemilihan layanan masing-masing sebesar 3,094\%, $4,444 \%$, dan $6,407 \%$. Dari ketiga nilai persentase tersebut, didapatkan rata-rata penurunan end-to-end delay pada pengujian pengaruh packet loss sebesar $4,648 \%$.

\subsection{Pengaruh Ketersediaan Layanan}

Salah satu faktor yang mempengaruhi kondisi yang dinamis ialah ketersediaan layanan. Beberapa hal yang dapat menyebabkan berkurangnya ketersediaan layanan bagi client yaitu:

- Penyedia layanan mengalihkan sumber daya untuk pekerjaan selain penyediaan layanan.

- Perangkat penyedia layanan keluar dari jaringan.

- Putusnya link antara klien dan penyedia layanan.

Berkurangnya ketersediaan layanan dapat disimulasikan menggunakan dua cara, yaitu:

- menghentikan layanan pada penyedia layanan, atau - memutus penyedia layanan dari jaringan.

Tabel 9. Skenario Pengaruh Ketersediaan Layanan

\begin{tabular}{cccc}
\hline Skenario & \multicolumn{3}{c}{ Status Layanan } \\
\cline { 2 - 4 } No. & RD1 & RD2 & RD3 \\
\hline 1 & Aktif & Tidak aktif & Aktif \\
2 & Aktif & Aktif & Aktif \\
3 & Aktif & Aktif & Tidak aktif \\
4 & Aktif & Tidak aktif & Tidak aktif \\
\hline
\end{tabular}

Tabel 9 menunjukkan skenario-skenario pengujian pengaruh ketersediaan layanan. Pada tiap skenario diatur status layanan (aktif/tidak aktif) secara sengaja pada masing-masing host RD1, RD2, dan RD3 dengan kombinasi keadaan yang berbedabeda, untuk melihat pengaruh ketersediaan layanan terhadap mekanisme pemilihan layanan. Detail masing-masing skenario pengujian pada Tabel 9 yaitu sebagai berikut:

1. Pada RD1 dan RD3, status layanan disetel aktif, sedangkan pada RD2 status layanan disetel tidak aktif.

2. Pada RD1, RD2, dan RD3 status layanan disetel aktif.

3. Pada RD1 dan RD2, status layanan disetel aktif, sedangkan pada RD3 status layanan disetel tidak aktif.

4. Pada RD1 status layanan disetel aktif, sedangkan pada RD2 dan RD3 status layanan disetel tidak aktif.

Pada tiap skenario diukur end-to-end delay rata-rata antara masing-masing klien dengan penyedia layanan, baik sebelum maupun sesudah dilakukan optimasi pada mekanisme pemilihan layanan. 
Hasilnya, setelah optimasi, klien selalu memilih layanan yang disediakan oleh penyedia layanan dengan end-to-end delay terendah, seperti pada pengujian pengaruh delay maupun pengujian pengaruh packet loss. Hal tersebut berbeda dengan sebelum dilakukan optimasi.

Perbandingan rata-rata end-to-end delay antara klien $(\mathrm{C} 1, \mathrm{C} 2$, dan $\mathrm{C} 3$ ) dengan penyedia layanan untuk pengujian pengaruh ketersediaan layanan, pada penerapan mekanisme pemilihan layanan sebelum dioptimasi dan sesudah dioptimasi, dapat dilihat pada Tabel 10, Tabel 11, dan Tabel 12. Dalam bentuk grafik, data perbandingan tersebut ditunjukkan pada Gambar 8, Gambar 9, dan Gambar 10.

Tabel 10. Rerata End-to-End Delay antara C1 dan Penyedia Layanan, pada Pengujian Pengaruh Ketersediaan Layanan

\begin{tabular}{ccc}
\hline Skenario & \multicolumn{2}{c}{ Rerata End-to-End Delay C1 (ms) } \\
\cline { 2 - 3 } No. & Praoptimasi & Pascaoptimasi \\
\hline 1 & 1,968 & 1,289 \\
2 & 1,847 & 1,219 \\
3 & 1,796 & 1,535 \\
4 & 1,675 & 1,749 \\
\hline Rata-rata & 1,822 & 1,448 \\
\hline
\end{tabular}

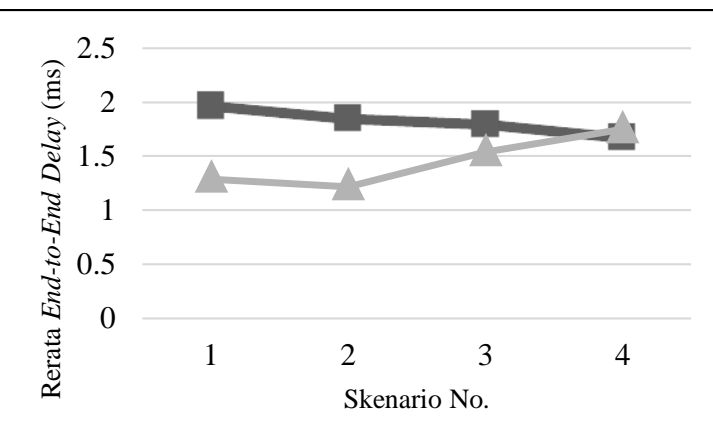

Rerata End-to-End Delay C1 (ms) Praoptimasi $\_$Rerata End-to-End Delay C1 (ms) Pascaoptimasi

Gambar 8. Grafik Rerata End-to-End Delay antara C1 dan Penyedia Layanan, pada Pengujian Pengaruh Ketersediaan Layanan

Tabel 11. Rerata End-to-End Delay antara C2 dan Penyedia Layanan, pada Pengujian Pengaruh Ketersediaan Layanan

\begin{tabular}{ccc}
\hline Skenario & \multicolumn{2}{c}{ Rerata End-to-End Delay C2 $(\mathbf{m s})$} \\
\cline { 2 - 3 } No. & Praoptimasi & Pascaoptimasi \\
\hline 1 & 1,264 & 1,321 \\
2 & 1,331 & 1,623 \\
3 & 1,233 & 1,399 \\
4 & 1,893 & 1,251 \\
\hline Rata-rata & 1,430 & 1,399 \\
\hline
\end{tabular}

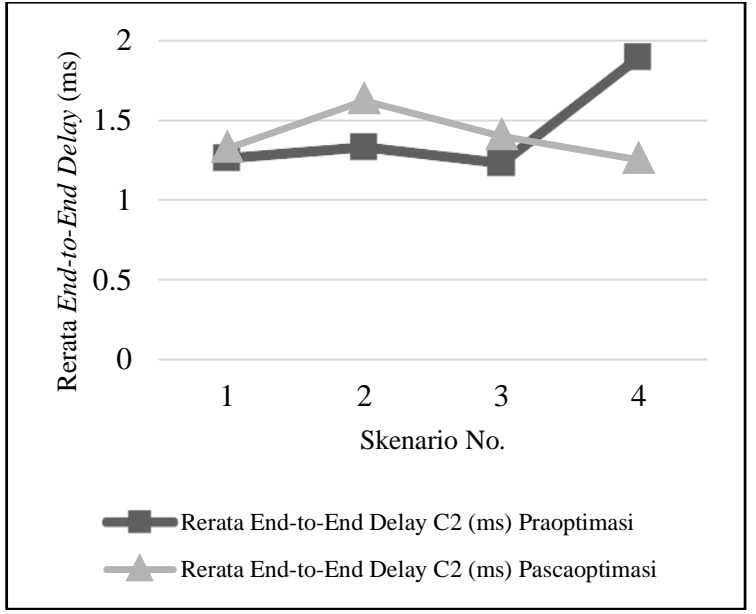

Gambar 9. Grafik Rerata End-to-End Delay antara C2 dan Penyedia Layanan, pada Pengujian Pengaruh Ketersediaan Layanan

Tabel 12. Rerata End-to-End Delay antara C3 dan Penyedia Layanan, pada Pengujian Pengaruh Ketersediaan Layanan

\begin{tabular}{ccc}
\hline Skenario & \multicolumn{2}{c}{ Rerata End-to-End Delay C3 $(\mathbf{m s})$} \\
\cline { 2 - 3 } No. & Praoptimasi & Pascaoptimasi \\
\hline 1 & 1,829 & 1,731 \\
2 & 1,888 & 1,133 \\
3 & 1,948 & 1,271 \\
4 & 1,398 & 1,713 \\
\hline Rata-rata & 1,766 & 1,462 \\
\hline
\end{tabular}

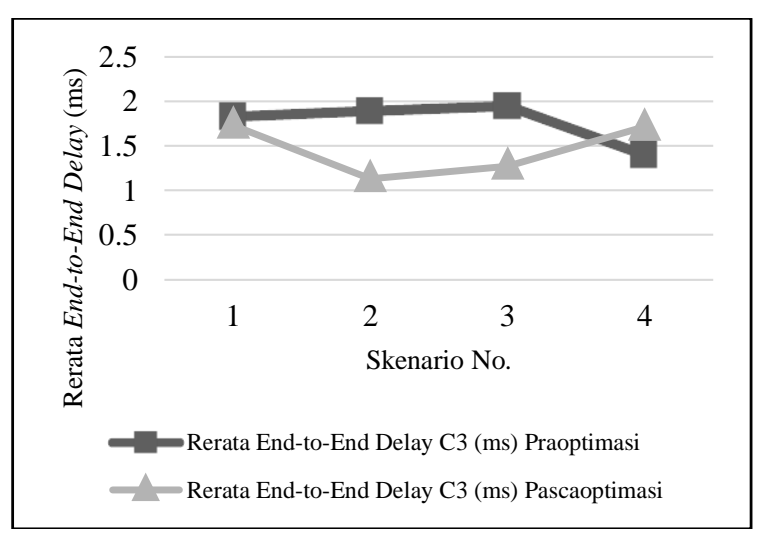

Gambar 10. Grafik Rerata End-to-End Delay antara C3 dan Penyedia Layanan,

pada Pengujian Pengaruh Ketersediaan Layanan

Pada Tabel 10, Tabel 11, dan Tabel 12 ditunjukkan pengaruh optimasi terhadap end-to-end delay rata-rata antara masing-masing klien dengan penyedia layanan yang terpilih. Khusus pada kasus C2 terjadi anomali. Pada Skenario 1, Skenario 2, dan Skenario 3, end-to-end delay rata-rata sesudah optimasi justru lebih tinggi daripada sebelum optimasi. Persentase peningkatan end-to-end delay tersebut masing-masing sebesar 4,509\%, 21,938\%, dan $13,463 \%$. Peningkatan tersebut bisa jadi dipengaruhi faktor lain, misalnya peningkatan beban kerja penyedia layanan yang terhubung dengan $\mathrm{C} 2$ pada saat pelaksanaan skenario-skenario pengujian. 
Meski pada beberapa skenario terjadi anomali, namun end-to-end delay rata-rata secara umum untuk keseluruhan skenario yang dijalankan tetap mengalami penurunan.

Persentase penurunan end-to-end delay ratarata pada pengujian pengaruh ketersediaan layanan untuk $\mathrm{C} 1, \mathrm{C} 2$, dan $\mathrm{C} 3$ antara sebelum dan sesudah optimasi pemilihan layanan masing-masing sebesar $20,505 \%, 2,220 \%$, dan 17,202\%. Dari ketiga nilai persentase tersebut, didapatkan rata-rata penurunan end-to-end delay pada pengujian pengaruh ketersediaan layanan sebesar 13,309\%.

\section{KESIMPULAN}

Dari hasil pengujian, dan analisis yang telah dilaksanakan, dapat ditarik beberapa kesimpulan. Kesimpulan yang pertama yaitu bahwa optimasi pemilihan layanan streaming multimedia berbasis $U P n P$ untuk kondisi dinamis dengan menggunakan metode dalam penelitian ini dapat menghasilkan penurunan besaran end-to-end delay rata-rata antara klien dengan penyedia layanan sebesar 35,343\%.

Kesimpulan kedua, secara rata-rata, optimasi pemilihan layanan dalam penelitian ini menghasilkan penurunan end-to-end delay antara klien dengan penyedia layanan. Namun, anomali terjadi pada skenario tertentu, yaitu naiknya end-toend delay rata-rata antara klien dengan penyedia layanan sesudah optimasi pemilihan layanan. Anomali tersebut bisa jadi dipengaruhi faktor lain, misalnya peningkatan beban kerja penyedia layanan yang terhubung dengan klien pada saat pengujian pengaruh ketersediaan layanan.

\section{REFERENSI}

DATA, M. 2014. Pemilihan Backup Node untuk Reduksi Feedback Implosion pada Reliable Multicast Protocol dengan Estimasi Bandwidth Availability dan Packet Loss. Tesis. Institut Teknologi Sepuluh Nopember.

GRIMMETT, J. \& O'NEILL, E. 2012. UPnP: Breaking out of the LAN. Wireless Communications and Networking Conference Workshops on Internet of Things Enabling Technologies, Embracing Machine-to-Machine Communications and Beyond, 170-174.

GUAN, S., DONG, X., WU, W., MEI, Y., LIAO, S. 2007. Trust Management and Service Selection in Pervasive Computing Environments. International Conference on Computational Intelligence and Security Workshops, 620-623.

HKCERT. 2013. Potential threats of Universal Plug and Play (UPnP) service exposure to the Internet.

[Online] https://www.hkcert.org/my_url/en/blog/130 22801. [Diakses: 18-Jun-2016].

JOHNSEN, F.T., FLATHAGEN, J., GAGNES, T., HAAKSETH, R., HAFSØE, T., HALVORSEN, J., NORDBOTTEN, N.A., \& SKJEGSTAD, M. 2008. Web Services and Service Discovery. Norwegian Defence Research Establishment (FFI). Forsvarets forskningsinstitutt.

KUROSE, J.F. \& ROSS, K.W.. 2013. Computer Networking: A Top-Down Approach (6th edition). Pearson Education, Inc.

NSRC (NETWORK STARTUP RESOURCE CENTER). Network Monitoring and Management: Network Delay. [Online]. https://nsrc.org/workshops/2016/rwnognmm/presentations/types-of-delay.pdf. [Diakses: 03-Jun-2016].

SZIGETI, T.; HATTINGH, C. 2004. Quality of Service Design Overview. Cisco Press. [Online] http://www.ciscopress.com/articles/article.a $\mathrm{sp}$ ? $\mathrm{p}=357102$ [Diakses: 5-Jun-2016]

UPnP FORUM. 2015. UPnP Device Architecture 2.0. Open Interconnect Consortium, Inc.

VERVERIDIS, C.N. \& POLYZOS, G.C. 2008. Service Discovery for Mobile Ad Hoc Networks: A Survey of Issues and Techniques. IEEE Communications Surveys, 10(3), 30-45. 